\title{
Anti-microbial and Anti-diabetic Activity of Six Seaweeds Collected from the Red Sea, Egypt
}

\author{
Nehal A.H.K. Osman ${ }^{2 *}$, Adel A. Siam³ ${ }^{3}$ Islam M. El-Manawy², You-Jin Jeon ${ }^{1}$ \\ ${ }^{1}$ Department of Marine Life Science, Jeju National University, Jeju, Republic of Korea \\ ${ }^{2}$ Botany Department, Faculty of Science, Suez Canal University, Ismailia, Egypt \\ ${ }^{3}$ Physiology Department, Faculty of Veterinary Medicine, Suez Canal University, Ismailia, Egypt
}

\begin{abstract}
Marine algae are a well-known source of active compounds with many biological activities. Many studies had point to the anti-microbial and anti-diabetic activity of seaweeds. Egyptian shores are rich with seaweeds, yet studies concerning their biological activity are inadequate. In the present work, the $80 \%$ methanolic extract of six seaweeds (Actinotrichia fragilis, Cystoseira myrica, Hormophysa cuneiformis, Laurencia papillosa, Sargassum cinereum, and Turbinaria turbinate) were tested for their antimicrobial activity using disc diffusion method and anti-diabetic activity using the Inhibition of $\alpha$-glucosidase method. The six species were collected from Hurghada, Red Sea, Egypt during late December, 2012. The results should that the algal extracts were effective against both Gram-positive and Gram-negative bacteria when used at $2000 \mu \mathrm{g} / \mathrm{disc}$ concentration. On Candida albicuns, both low and high concentrations showed activity. For anti-diabetic activity, H. cuneiformis was the most active species that reached to 53\% inhibition of $\alpha$-glucosidase at the highest concentration $(1000 \mu \mathrm{g} / \mathrm{ml})$ with $\mathrm{IC}_{50} 676.9 \mu \mathrm{g} / \mathrm{ml}$. In conclusion, the tested seaweeds possess a good anti-microbial and anti-diabetic activity, especially the species Hormophysa cuneiformis.

Keywords: Seaweed, Hormophysa cuneiformis, Actinotrichia fragilis, $\alpha$-glucosidase, anti-microbial, antidiabetic
\end{abstract}

\section{INTRODUCTION}

Diabetes and antibiotic-resistance microbes are becoming a great problem that the world is facing nowadays (Palanisamy et al.,2014; WHO, 2015). According to the World Health Organization (WHO), many of the antimicrobial drugs that have been discovered could become ineffective due to anti-microbial resistant (WHO, 2015). Likewise, diabetes is becoming a world-wide disease as a result of im-balanced diet, obesity, and stress (WHO, 2017). Diabetes could be treated using drugs that inhibiting $\alpha$-glucosidase and $\alpha$ amylase enzymes, which capable of breaking the starch into glucose before its uptake into the bloodstream (Krentz and Bailey, 2005). Although acarbose is a well-known anti-diabetic drug, it could reason in many harmful effects such as abdominal disorder and diarrhea which reduce patient submission to the drug and treatment effectiveness (Kumar et al., 2011). There for, the searching for efficient therapeutic natural drugs with less side-effect and new mechanism of action is required. Marine algae, Known as seaweeds, are a well-known healthy food source for many Asian countries for centuries (Lee and Jeon, 2013). Seaweeds secondary metabolites may offer coverage for the need of novel bioactive compounds with many biological activities (Unnikrishnanand Jayasri, 2018). Seaweeds and seaweed-derived bio-active compounds have been exploited as functional foods with therapeutic uses (Akbarzadeh et al., 2018). Phyto-chemical investigations on seaweeds discovered rich varieties of biologically-active substances with antioxidant, antimicrobial, anti-diabetic, anti-inflammation, anticoagulant and antitumor activities (Lee and Jeon, 2013; Unnikrishnanand Jayasri, 2018). Red Sea is considered a valuable source of many types of seaweed that still need to be explored for their bio- activity. Therefore, the present study conducted to evaluate the anti-microbial and anti- diabetic activity for six Red Sea seaweeds that have a few studies upon their bioactivity.

\section{MATERIALS AND METHODS}

\section{Sample collection and preparation}

The six seaweeds (Actinotrichia fragilis, Cystoseira myrica, Hormophysa cuneiformis, Laurencia papillosa, Sargassum cinereum, and Turbinaria turbinate) were collected from the intertidal and subtidal zones from Hurghada reefs during late December, 2012. Fresh samples were washed in seawater to remove encrusting material, thoroughly washed with fresh water to remove excess salt and air dried in shade then grinded. Each grinded algal sample was mixed with $80 \%$ methanol, putted in a shaking incubator at $25^{\circ} \mathrm{C}$ overnight and then the extract was collected. The process was repeated three times or till the methanol extract became clear and it was combined together. The extract were then filtered through Whatman No.4 filter paper and evaporated to dryness under reduced pressure vacuum. The crude extract was dissolved in dimethyl sulfoxide (DMSO) to prepare a $50 \mathrm{mg} / \mathrm{ml}$ stock solution.

\footnotetext{
Antimicrobial disc diffusion assay Tested organisms and culture conditions

Standard isolates of Bacillus subtiles (B.s., ATCC 813106), Staphylococcus aureus (S.a., ATCC 25923) as gram positive bacteria, Escherichia coli (E.c., ATCC 25922) as gram negative bacteria, and Candida albicans (C.a., ATCC 16404) as fungus were acquired from the American type culture collection (ATCC). The bacterial organisms, the B.s, E.c and S.a, were stored on Muller Hinton agar (MHA) slants and were propagated in nutrient broth media. The fungal organism (C.a.) was stored on Sabouraud Dextrose Agar (SDA) medium and were propagated in Yeast Extract pepton Glucose medium (YPG).
} 


\section{Antimicrobial test}

Antimicrobial tests were carried out by disc diffusion method (Atlas and Unterman, 1999) using $100 \mu \mathrm{l}$ of a suspension containing $10^{8} \mathrm{cfu} / \mathrm{ml}$ of the bacteria and $10^{6} \mathrm{cfu} / \mathrm{ml}$ of the fungus; all were spread on MHA and SDA medium, respectively. The discs were impregnated with 200 and $2000 \mu \mathrm{g} / \mathrm{disc}$ and located on the inoculated agar. Negative control was designed using the same solvents used in dissolving the algal extract (DMSO). Augmentin (AG), Chloramphenicol (C), and Streptomycin (S) were used as positive control at a concentration of $30 \mu \mathrm{g} / \mathrm{disc}$ to determine the sensitivity of each tested microbial species. The inoculated plates were incubated at $37^{\circ} \mathrm{C}$ for $24 \mathrm{~h}$ for clinical bacterial strains and $48 \mathrm{~h}$ for the fungus. Antimicrobial activity was evaluated by measuring the inhibition zone of the extracts against the tested organisms.

\section{Anti-diabetic activity: The effect of algal samples on the Inhibition of $\alpha$-glucosidase}

The chromatographic method described by Lee et al. (2010) was used to perform the $\alpha$-glucosidase inhibitory assay. Briefly, yeast $\alpha$-lucosidase $(0.7 \mathrm{U}$, Sigma) was dissolved in 100mM DPBS (pH 7.0) as an enzyme solution. Five $\mathrm{mM}$ of $\mathrm{p}$-Nitrophenyl-a-Dglucopyranoside in the same buffer $(\mathrm{pH} 7.0)$ was used as a substrate solution. In a 96 -well plate, a $100 \mu 1$ of enzyme solution and $20 \mu \mathrm{l}$ of each algal extract in different concentrations were mixed. The absorbance was measured at $405 \mathrm{~nm}$ at zero time. The mixture was incubated for $5 \mathrm{~min}$ then the substrate solution $(100 \mu \mathrm{l})$ was added and incubated for another $5 \mathrm{~min}$ at room temperature. Increasing the absorbance from zero time was measured and compared to a control that contains buffer solution in place of the extract. The blank was prepared via replacement of the enzyme solution with buffer solution and absorbance was recorded. Acarbose was used as a positive control. The $\alpha$-glucosidase inhibitory activity was expressed as inhibition $\%$ and was calculated as following:

$$
\% \text { Inhibition }=\frac{\left(\mathrm{C}_{\mathrm{A}}-\mathrm{C}_{\mathrm{B}}\right)-\left(\mathrm{S}_{\mathrm{A}}-\mathrm{S}_{\mathrm{B}}\right)}{\left(\mathrm{C}_{\mathrm{A}}-\mathrm{C}_{\mathrm{B}}\right)}
$$$$
\text { Where, }
$$

$\mathrm{C}_{\mathrm{A}}=$ Control after enzyme treatment.

$\mathrm{C}_{\mathrm{B}}=$ Control before enzyme treatment.

$\mathrm{S}_{\mathrm{A}}=$ Sample after enzyme treatment.

$\mathrm{S}_{\mathrm{B}}=$ Sample before enzyme treatment.

\section{RESULTS}

The antimicrobial activity study revealed that the algal extracts were effectively suppressed the growth of most of the tested microorganisms in a behavior comparable to the commercial antibiotics that were used as positive control. All the algal extracts were effective against both Gram-positive and Gramnegative bacteria when used at $2000 \mu \mathrm{g} / \mathrm{disc}$ concentration, whereas the concentration of $200 \mu \mathrm{g} / \mathrm{disc}$ was less effective (Table 1). For Escherichia coli the extracts of $A$. fragilis and $H$. cuneiformis were the only effective extracts at the low concentration. At the high concentration all the extracts showed activity keeping A. fragilis and $H$. cuneiformis to be the most effective (Fig. 1-A). L. papillosa was the only effective extract on Staphylococcus aureus at the low concentration. At the high concentration, all the extracts were effective against $S$. aureus showing $H$. cuneiformis and $T$. turbinate to be the highest among them (Fig.1-B). For Bacillus subtiles, the extract of $H$. cuneiformis was the most effective extract on both concentrations. At low concentration, C. myrica, L. papillosa, and $S$. cinereum did not show any activity on $B$. subtiles, while demonstrate a good activity at the high concentration (Fig. 1-C). On Candida albicuns, both low and high concentrations of the six extracts showed activity. The extract of $A$. fragilis was the most effective at the low concentration, while at the high concentration both $A$. fragilis and C. myrica were the most effective (Fig.1D).

Table 1: Antimicrobial activity test of $80 \%$ methanol algal extracts at two concentrations (1 and 2$)$ in comparison with negative

\begin{tabular}{|c|c|c|c|c|c|}
\hline Sample & Treat. & E. coli & S. aureus & B. subtiles & C. albicans \\
\hline Negative Control & DMSO & -ve & -ve & -ve & -ve \\
\hline \multirow{3}{*}{ Positive control } & $\mathrm{AG}$ & $12 \pm 0.23$ & $10 \pm 0.12$ & $10 \pm 0.25$ & -ve \\
\hline & $\mathrm{C}$ & $11 \pm 0.12$ & $17 \pm 0.17$ & $15 \pm 0.06$ & $18 \pm 0.12$ \\
\hline & $\mathrm{S}$ & $10 \pm 0.17$ & $20 \pm 0.07$ & $19 \pm 0.06$ & -ve \\
\hline \multirow{2}{*}{ A. fragilis } & 1 & $6^{\mathrm{a}} \pm 0.12$ & -ve & $6^{\mathrm{c}} \pm 0.06$ & $8.5^{\mathrm{a}} \pm 0.01$ \\
\hline & 2 & $8^{\mathrm{a}} \pm 0.17$ & $7.5^{\mathrm{b}} \pm 0.01$ & $7^{d} \pm 0.12$ & $11^{\mathrm{a}} \pm 0.06$ \\
\hline \multirow[t]{2}{*}{ C. myrica } & 1 & -ve & -ve & -ve & $7^{\mathrm{c}} \pm 0.06$ \\
\hline & 2 & $7^{\mathrm{c}} \pm 0.06$ & $7.5^{\mathrm{b}} \pm 0.6$ & $7.5^{\mathrm{c}} \pm 0.1$ & $11^{\mathrm{a}} \pm 0.12$ \\
\hline \multirow{2}{*}{ H. cuneiformis } & 1 & $6^{\mathrm{a}} \pm 0.12$ & -ve & $8.5^{\mathrm{a}} \pm 0.01$ & $6^{\mathrm{e}} \pm 0.06$ \\
\hline & 2 & $8^{a} \pm 0.6$ & $9^{\mathrm{a}} \pm 0.12$ & $10.5^{\mathrm{a}} \pm 0.2$ & $6.5^{\mathrm{e}} \pm 0.12$ \\
\hline \multirow[t]{2}{*}{ L. papillosa } & 1 & -ve & $6.5 \pm 0.06$ & -ve & $6.5^{\mathrm{d}} \pm 0.01$ \\
\hline & 2 & $7.5^{\mathrm{b}} \pm 0.1$ & $7^{\mathrm{c}} \pm 0.1$ & $7.5^{\mathrm{e}} \pm 0.2$ & $8^{c} \pm 0.12$ \\
\hline \multirow[t]{2}{*}{ S. cinereum } & 1 & -ve & -ve & -ve & $7.5^{\mathrm{b}} \pm 0.01$ \\
\hline & 2 & $6.5^{\mathrm{d}} \pm 0.1$ & $6^{\mathrm{d}} \pm 0.12$ & $6^{\mathrm{f}} \pm 0.12$ & $9^{\mathrm{b}} \pm 0.06$ \\
\hline \multirow[t]{2}{*}{ T. turbinata } & 1 & -ve & -ve & $8^{b} \pm 0.12$ & $6^{\mathrm{e}} \pm 0.06$ \\
\hline & 2 & $7.5^{\mathrm{b}} \pm 0.1$ & $9^{\mathrm{a}} \pm 0.12$ & $8.5^{\mathrm{b}} \pm 0.1$ & $7^{\mathrm{d}} \pm 0.6$ \\
\hline
\end{tabular}
control (DMSO) and $30 \mu \mathrm{g} /$ disc of three commercial controls (AG, C and S).

For treatment (Treat.): AG refers to Augmentin antibiotic; $\mathrm{C}$ to Chloramphenicol; S to Streptomycin; 1 to $200 \mu \mathrm{g} /$ disc as algal extract concentration, and 2 to $2000 \mu \mathrm{g} / \mathrm{disc}$. Each value below the microbial name is the mean of the inhibition zone (mm) of $3 \mathrm{replica} \pm \mathrm{SD}$. Within the same column, means carrying different superscripts are significantly different from each other at $\mathrm{P} \leq 0.05$ or less. 


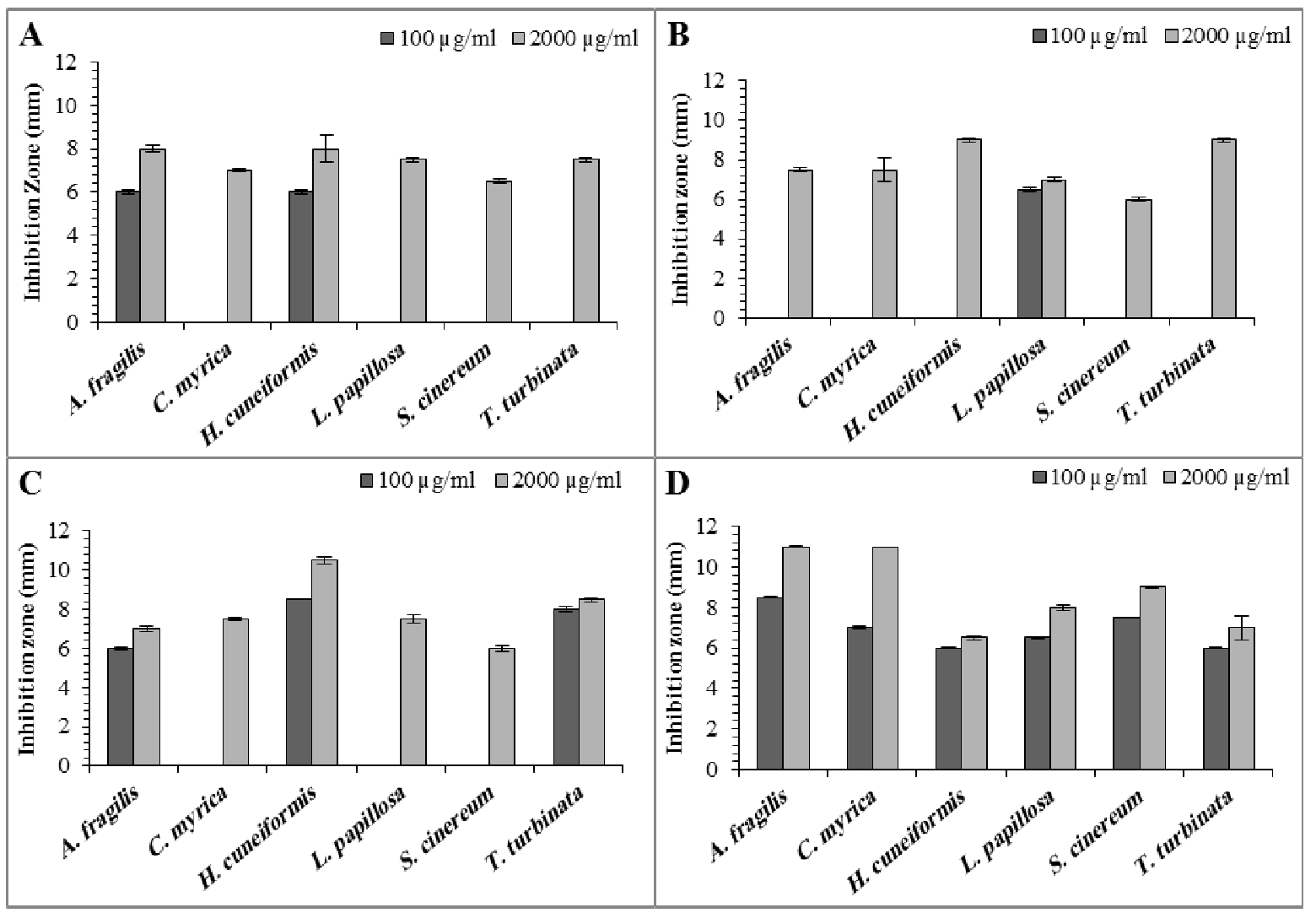

Figure 1: Comparison of the inhibition zone for the six studied $80 \%$ methanol seaweed extracts at two concentrations (100 and 2000 $\mu \mathrm{g} / \mathrm{disc})$ against different microorganisms, where $\mathrm{A}=($ E. coli $), \mathrm{B}=($ S. aureus $), \mathrm{C}=($ B. subtiles $), \mathrm{D}=($ C. albicans $)$. The values expressed as mean of triplicate $\pm \mathrm{SD}$.

The results for the $\alpha$-glucosidase inhibitory activity showed that $H$. cuneiformis was the most active species that reached to $53 \% \pm 2.3$ inhibition at the highest concentration $(1000 \mu \mathrm{g} / \mathrm{ml})$ followed by $A$. fragilis with $51.27 \% \pm 2.2$ inhibition at the same concentration (Fig. 2).

Furthermore, the inhibitory effectiveness was compared on the basis of $\mathrm{IC}_{50}$. The results in Table 2 showed that the extract of $H$. cuneiformis had the lowest $\mathrm{IC}_{50}(676.9 \pm 2.5 \mu \mathrm{g} / \mathrm{ml})$ among the studied species. A. fragilis showed higher $\operatorname{IC}_{50}(920 \pm 1.3$ $\mu \mathrm{g} / \mathrm{ml}$ ), while the rest of the species did not reach to $50 \%$ inhibition. For comparison, the Acarbose, the commercial positive control used in this study, inhibited the activity of $\alpha$-glucosidase to $85.6 \%$ at the $1000 \mu \mathrm{g} / \mathrm{ml}$ concentration with $\mathrm{IC}_{50} 417.9 \pm 0.5 \mu \mathrm{g} / \mathrm{ml}$.

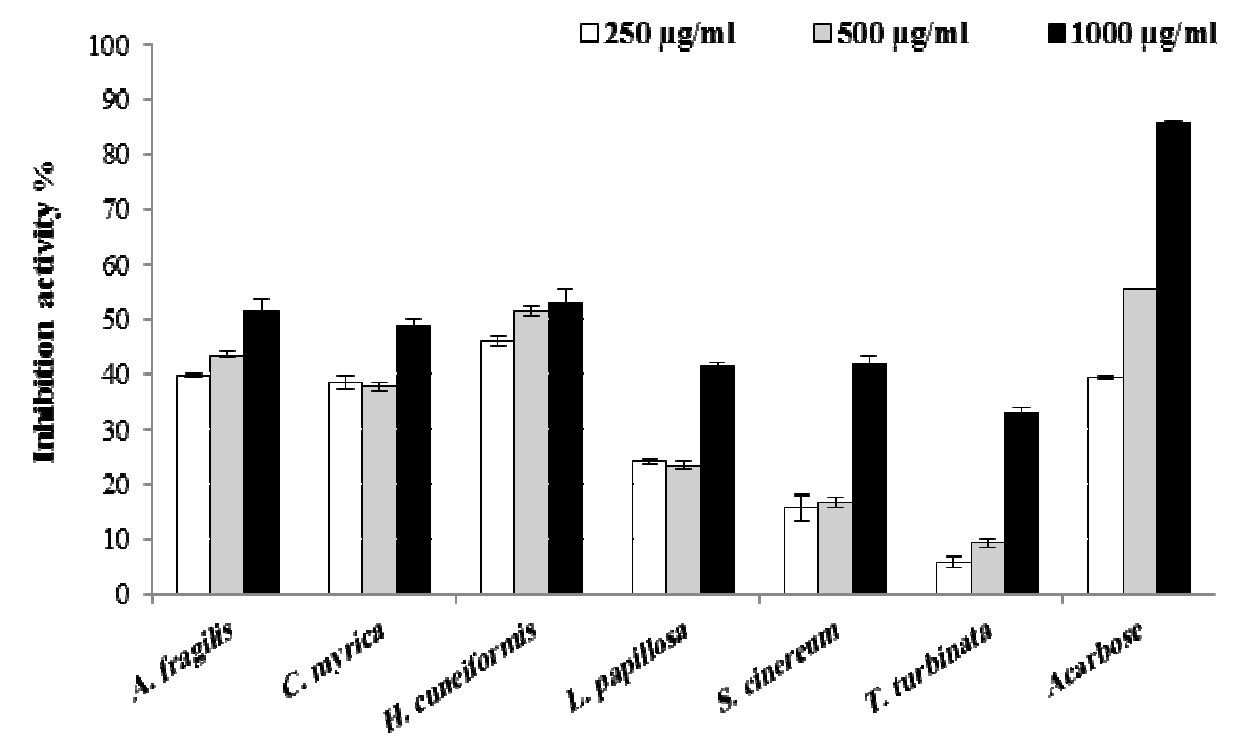

Figure 2: Inhibitory effect of $80 \%$ methanol extract of the six studied seaweeds on $\alpha$-glucosidase. Acarbose was selected as a positive control for inhibition. Inhibition is expressed as mean of triplicate \pm SD. 
Table 2: Representing the $\mathrm{IC}_{50}$ values for the $80 \%$ methanol extract of the six studied seaweeds inhibitory effect and acarbose on $\alpha$-glucosidase. The values of $\mathrm{IC}_{50}$ were determined in triplicate.

\begin{tabular}{|c|c|c|c|c|c|c|}
\hline & & & $\mathrm{IC}_{50}$ in $\mu \mathrm{g} / \mathrm{ml}$ & & & \\
\hline $\begin{array}{l}\text { A. fragilis } \\
920^{\mathrm{a}} \pm 1.3\end{array}$ & $\begin{array}{l}\text { C. myrica } \\
>1000\end{array}$ & $\begin{array}{l}\text { H. cuneiformis } \\
\mathbf{6 7 6 . 9}^{\mathbf{b}} \pm 2.5\end{array}$ & $\begin{array}{l}\text { L. papillosa } \\
>1000\end{array}$ & $\begin{array}{l}\text { S. cinereum } \\
>1000\end{array}$ & $\begin{array}{l}\text { T. turbinata } \\
>1000\end{array}$ & $\begin{array}{l}\text { Acarbose } \\
\mathbf{4 1 7 . 9}^{\mathbf{c}} \pm 0.5\end{array}$ \\
\hline
\end{tabular}

Within the same column, means carrying different superscripts are significantly different from each other. $\mathrm{P} \leq 0.05$ was accepted as an indication of statistical significance difference.

\section{DISCUSION}

Oxidative stress, Diabetes, resistant-microbes had become serious public problems for health worldwide in developing and advanced nations. Most of these diseases are formed from bad nutritional habits and go along with the increased production of the free radicals and/or insufficient antioxidant defense systems (Pitozzi et al., 2003). Seaweeds are proved to stand as a good source of natural bioactive compounds with many therapeutic activities (Ambreen et al., 2012).

In the present study, the $80 \%$ methanol extracts of six studied algal species were investigated for in vitro antimicrobial activity. The antimicrobial activity test showed that the extracts had broad spectrum effect against most species under investigation at the higher concentration $(2000 \mu \mathrm{g} / \mathrm{ml})$. The effect against Grampositive bacteria ( $S$. aureus and $B$. subtiles) and $C$. albicans were more relatively conspicuous than Gramnegative $(E$. coli) and that effect was dose dependent, which increased with concentration. The result was agreed with Gonzalez del Val et al. (2001), Demirel et al. (2009) Taskin et al. (2007), Kandhasamy and Arunachalam (2008). The present results indicated that $H$. cuneiformis was the most effective species against the studied microorganisms except for C. albicans, Actinotrichia fragilis found to be the most effective species. The current results could be different from other results obtained in previous studies due to several factors. This may be owing to the method of extraction, the operated solvents, and season at which species were collected that would give rise to different susceptibilities of the target strains (Kandhasamy and Arunachalam, 2008). Many bioactive compounds from marine macro-algae were verified to possess antimicrobial activity including phenolic compounds hydrocarbons, terpenes, acids, phenols, sulfurcontaining compound, aldehydes, naphthalene skeleton and alcohols (Bansemir et al., 2006). Fatty acids and sterols considered to be one of the most bioactive compounds with antimicrobial activity (Demirel et al., 2009).

Diabetes type II is a metabolic disorder syndrome diagnosed by hyperglycemia, owing to the lessened insulin secretion, insulin activity or both cases (Akbarzadeh et al., 2018). The major goal of the antidiabetic drugs is to lower sugar blood level by suppressing the gastrointestinal absorption of glucose through the inhibition of either $\alpha$-glucosidase or $\alpha$ amylase (Krentz and Bailey, 2005). The presently available treatments for diabetes-type II include insulin and several oral drugs. Though, these treatments have either imperfect efficiency or side effects. Therefore, recently, there has been increasing demand of using alternative natural products for diabetes therapy, especially those derived from plants due to their less toxic with fewer side effects than synthetic ones (Lee and Jeon, 2013). Many researches have been reported seaweeds for its anti-diabetic activity (ex. Kim et al., 2012; Jensen et al., 2013; Akbarzadeh et al., 2018; Unnikrishnan and Jayasri, 2018). Therefore, the six studied species was screened for their anti-diabetic effect via the inhibition of $\alpha$-glucosidase in the presence of acarbose as positive control. The result indicated that $H$. cuneiformis is the most active species in inhibiting $\alpha$-glucosidase with. The rest of the species did not reach to $50 \%$ inhibition at the studied concentrations. The result is considered lower than those obtained by Lee and Jeon (2013), and Akbarzadeh et al., 2018 that maybe due to the difference in environmental and geographical conditions. Many compounds from seaweeds proved to have anti- diabetic activity such as polysaccharides, fucoxanthin, Polyphenols as well as some minerals including, zinc, magnesium, potassium and calcium (Lakshmanasenthil et al., 2014; Unnikrishnan and Jayasri, 2018).

\section{CONCLUSION}

In conclusion, the seaweeds under investigation could be a source for developing anti-microbial and anti-diabetic drugs especially Hormophysa cuneiformis and Actinotrichia fragilis. More studies are required in order to isolate, purify and identify the bioactive compounds responsible for their bioactivities.

\section{REFERENCE}

AKBARZADEH, S., H. GHOLAMPOUR, P. FARZADINIA , A. DANESHI, B. RAMAVANDI, A. MOAZZENI, M. KESHAVARZ, AND A. BARGAHI. 2018. Anti-Diabetic Effects Of Sargassum Oligocystum on StreptozotocinInduced Diabetic Rat. Iran J Basic Med Sci, 21: 342-346.

AMBREEN A., K. HIRA, A. TARIQ, RUQQIA, V. SULTANA, AND J. ARA. 2012. Evaluation Of Biochemical Component and Antimicrobial Activity of Some Seaweeeds Occurring At Karachi Coast. Pak J Bot., 44: 1799-1803.

ATLAS R.M. AND R. UNTERMAN. 1999. Bioremediation. In: Demain A, Davies J, Atlas RM (eds). Manual of industrial microbiology and biotechnology, 2nd edn. Societies and Associations, 666-681.

BANSEMIR A., M. BLUME, S. SCHRÖDER AND U. LINDQUIST. 2006. Screening of cultivated seaweeds for antibacterial activity against fish pathogenic bacteria. Aquaculture, 252: 79-84.

DEMIREL Z., F.F. YILMAZ-KOZ, U. KARABAYYAVASOGLU, G. OZDEMIR, AND A. SUKATAR. 2009. Antimicrobial and antioxidant 
activity of brown algae from the Aegean Sea. $J$. Serb. Chem. Soc., 74: 619-628.

GONZALEZ DEL VAL A., G. PLATAS, A. BASILIO, A. CABELLO, J. GORROCHATEGUI, I. SUAY, F. VICENTE, E. PORTILLO, M. JIMENEZ DEL RIO, G.G. REINA AND F. PELAEZ. 2001. Screening of Antimicrobial Activities in Red, Green and Brown Macroalgae from Gran Canaria (Canary Islands, Spain). Int. Microbiol., 4: 35-40.

JENSEN G.M., C. PEDERSEN, M. KRISTENSEN, G. FROST, AND A. ASTRUP. 2013. Review: Efficacy of Alginate Supplementation In Relation To Appetite Regulation and Metabolic Risk Factors: Evidence From Animal and Human Studies. Obes Rev., 14: 129-44.

KANDHASAMY M. AND K.D. ARUNACHALAM. 2008. Evaluation of in vitro Antibacterial Property of seaweeds of southeast Coast of India. African Journal of Biotechnology, 7: 1958-1961.

KANG J.Y., M.N.A. KHAN, N.H. PARK, J.Y. CHO, M.C. LEE, H. FUJII, AND Y.K. HONG. 2008. Antipyretic, Analgesic, and Anti-inflammatory Activities of the seaweed Sargassum fulvellum and Sargassum thunbergii in mice. J. Ethnopharmacol., 116 : 187-190.

KIM K.J., K.Y. YOON, AND B.Y. LEE. 2012. Fucoidan Regulate Blood Glucose Homeostasis in C57BL/KSJ $\mathrm{m}+/+\mathrm{db}$ and $\mathrm{C} 57 \mathrm{BL} / \mathrm{KSJ} \mathrm{db} / \mathrm{db}$ mice. Fitoterapia., 83: 1105-9.

KRENTZ A.J. AND C.J. BAILEY. 2005. Oral Antidiabetic Agents - Current Role In Type 2 Diabetes Mellitus. Drugs, 65: 385-411.

KUMAR S., V. KUMAR AND M.S. CHANDRASHEKHAR. 2011. In-vitro Antioxidant and Alpha-Amylase Inhibitory Activity of Isolated Fraction from Methanolic Extract of Asystasia Dalzelliana Leaves. Int. J.PharmTech Res, 3: 889-894.

LAKSHMANASENTHIL S., T. VINOTHKUMAR, D. GEETHARAMANI, T. MARUDHUPANDI, G.
SUJA, AND N.S. SINDHU. 2014. Fucoidan-A Novel A-Amylase Inhibitor from Turbinaria Ornata with Relevance to NIDDM Therapy. Biocatal Agric Biotechnol, 3: 66-70.

LEE S.H., J.S. HAN, S.J. HEO, H. WANG, AND Y.J. JEON. 2010. Protective Effects of Dieckol Isolated Form Ecklonia Cava Against High GlucoseInduced Oxidative Stress in Human Umbilical Endothelial Cells. Toxicology in Vitro, 24: 375-381.

LEE, S.H. AND Y.J. JEON. 2013. Anti-Diabetic Effects of Brown Algae Derived Phlorotannins, Marine Polyphenols Through Diverse Mechanisms. Fitoterapia, 86: 129-136.

PALANISAMY S., S. SUDHA, AND S. PRAKASH. 2014. Antidiabetic Activity of Aqueous Extract of Padina Boergesenii in Streptozotocin-Induced Diabetic Rates. Int J Pharm Pharm Sci, 6: 418-422.

PITOZZI V., L. GIOVANNELLI, G. BARDINI, C.M. ROTELLA, AND P. DOLARA. 2003. Oxidative DNA Damage in Peripheral Blood Cells in Type 2 Diabetes Mellitus: Higher Vulnerability Of Polymorphonuclear Leukocytes. Mutat Res., 529: 129133.

TASKIN, E., M. OZTURK, E. TASKIN, AND O. KURT. 2007. Antibacterial Activities of Some Marine Algae from the Aegean Sea (Turkey). African Journal of Biotechnology, 6: 2746-2751.

UNNIKRISHNAN, P.S. AND M.A. JAYASRI. 2018. Marine Algae as a Prospective Source For Antidiabetic Compounds - A Brief Review. Current Diabetes Reviews, 14: 237-245.

WORLD HEALTH ORGANIZATION (WHO). Antimicrobial resistance Fact sheet 2015. (visited on 7 March 2018/ last modified January 2018). http://www.who.int/mediacentre/factsheets/fs194/e $\mathrm{n} /$.

WORLD HEALTH ORGANIZATION (WHO). DIABETES KEY FACTS 2017. (visited on 7 March 2018). http://www.who.int/news-room fact-sheets detail/diabetes. 
النشاط المضاد للبكتيريا ومضاد للسكري لستة أعشاب بحرية تم جمعها من البحر الأحمر ، مصر

نهال عثمان 2 ، عادل أحمد صيام 3 ، إسلام محمد المناوي 2 ، يو جين جيون 1

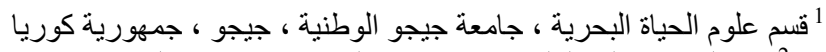

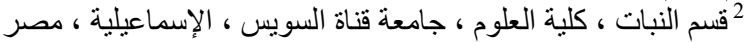

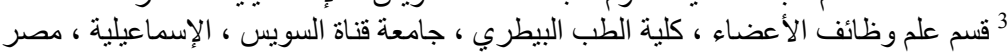

الملخص العربـــي

يهدف العمل الحالي لتقيم الخصائص العلاجية لمستخلصات ستة أنو اع من الطحالب البحرية و التي جمعت من مناطق الشعاب المرجانية بالغردقة الواقعة على البحر الأحمر وهي سيستوزير ا ميريكا، هورموفيزا كيونيفورمز، سر اجسيوم سينيريوم، تربيناريا تربيناتا ، اكتينوتريشيا فر اجيليس و لور انسيا بابيلوزا. وقد تم تقييم هذه الطحالب عن طريق قياس النشاط المحتمل لهذه المستخلصات كمضاد للميكروبات و مرض السكري. وقد اتبعت فى تقدير ذلك عدد من الطرق و المر اجع العلمية المستخدمة فى تعريف الطحالب وتقدير القيم السابق ذكر ها. وقد اسفرت الدر اسه على ما يلى:النشاط المضاد للميكروبات : اظهرت مستخلصات الطحالب فاعليتها في تثبيط نمو معظم الميكروبات قبد الدراسة في سلوك مماثل للمضادات الحيوية التجارية. وقد كان هذا التاثير بصورة اوضح في التركيز الاعلي (2000 ميكروجرام) وكانت جميع مستخلصات الطحالب فعالة ضد كل من البكتيريا إيجابية

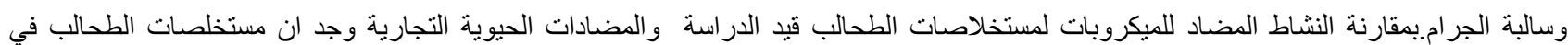
التركيز الاعلي قد تكون مماتله في الفاعلية ضد الميكروبات. النشاط المضاد لمرض السكري : و فقا للار اسة، كان طحلب الهورموفيزا الأكثر نشاطا من بين الطحالب قيد الدر اسة في تنبيط انزيم الالفاجلوكوسيداز. وجاء طحلب الاكتينوتريثيا في المركز الثاني من حيث تثبيط الانزيم. بينما لم تظهر باقي الطحالب تاثير اذو اهمية. ومن جهة أخرى، أظهر الدواء التجاري لمكافحة السكري (الاكربوس) اعلي ناثير في تثبيط الانزيم. 